\title{
PENGGUNAAN IT DALAM PROYEK NEW PRODUCT DEVELOPMENT DI INDONESIA: IDENTIFIKASI FAKTOR PENENTU DAN DAMPAK KINERJA PROYEK
}

\author{
Boy Bayu Idisondjaja \\ Program Manajemen Pemasaran, Sekolah Tinggi Manajemen PPM \\ BBI@ppm-manajemen.ac.id \\ Pepey Riawati Kurnia \\ Program Manajemen Pemasaran, Sekolah Tinggi Manajemen PPM \\ PRK@ppm-manajemen.ac.id \\ Siti Nuraisyah Suwanda \\ Program Manajemen Pemasaran, Sekolah Tinggi Manajemen PPM \\ SNS@ppm-manajemen.ac.id
}

\begin{abstract}
ABSTRAK
Penelitian ini merupakan sebuah replikasi penelitian Determinants of IT Usage and New Product Performance oleh Barczak, Sultan, dan Gultink (2007) dengan mengambil geografi dan karakteristik responden perusahaan menengah dan besar di Indonesia. Tujuan dari penelitian adalah untuk mengidentifikasi faktor antesenden penggunaan perangkat IT. Tujuan kedua adalah untuk menggali lebih jauh peran IT dalam membangun kapabilitas inovasi yang menghasilkan nilai bagi perusahaan. Penelitian menggunakan pendekatan kuantitatif dengan rancangan konklusif single cross-sectional design untuk menguji delapan hipotesis melalui pengukuran regresi berganda (multiple regression). Delapan variabel yang akan diuji terbagi dua kelompok besar yaitu kelompok variabel penentu (resiko proyek, eksistensi 'champion', otonomi, iklim inovatif perusahaan, infrastruktur IT, keterlekatan penggunaan IT) dan dampak kinerja penggunaan IT (kecepatan peluncuran produk ke pasar, kinerja pasar). Hasil penelitian menunjukan variabel keterlekatan penggunaan IT, iklim inovatif, infrastruktur IT, resiko proyek memiliki hubungan yang positif dan cukup berpengaruh sehingga lebih menentukan penggunaan IT dalam NPD dibanding variabel penentu lainnya. Sementara itu, dampak penggunaan IT kepada kinerja proyek lebih ditunjukan oleh variabel kecepatan peluncuran produk ke pasar melalui hubungan yang positif dan signifikan dibanding variabel kinerja pasar. Manfaat dari hasil penelitian ini di antaranya adalah dapat memberikan alternatif tindakan bagi para manajer untuk meningkatkan penggunaan IT dalam proses New Product Development (NPD).
\end{abstract}

\section{Kata Kunci :}

New Product Development, Penggunaan IT, Faktor Penentu, Dampak Kinerja.

\begin{abstract}
This research is a research replication of Determinants of IT Usage and New Product Performance by Barczak, Sultan, and Gultink (2007), adapted using the characteristics of different respondents which are medium and large companies in Indonesia. The first purpose of the research is to identify antecedents of the use of IT tools. The second purpose is to further explore the role of IT in building innovative capabilities that generate values for the company. The study used a quantitative approach with a single cross-sectional conclusive design to test eight hypotheses through multiple regression measurements. The eight variables to be tested are divided into two major groups, namely the determinant variable (project risk, existence of a champion, autonomy, innovative climate, IT infrastructure, IT usage depth) and impact of IT usage performance (speed of product launch to market, market performance). The result of the research shows that the variables of IT usage depth, enterprise innovative climate, IT infrastructure, and project risk have a positive and influential relationship therefore determine the use of IT in NPD than other determinant variables. Meanwhile, the impact of IT usage on project performance is affected by the speed of product launch to market with a positive and significant relationship compared to market performance variable. The practicalities of this research, among others, is to provide an alternative action for managers to increase the use of IT in the process of New Product Development (NPD).
\end{abstract}

Kata Kunci :

New Product Development, IT Usage, Antecedents, Impact on Performance 


\section{PENDAHULUAN}

\section{Latar Belakang}

Teknologi informasi (Information Technology/IT) telah digunakan dalam berbagai aktivitas perusahaan tidak terkecuali dalam proses New Product Development (NPD). Perangkat IT disebut sebagai salah satu sumber kapabilitas perusahaan berkenaan dengan posisi kemampu-bersaingan di dalam arena persaingan (Farrell, 2003; Sambarmurthy dan Zmud, 2000). Songs et.al (2007) menjelaskan perangkat IT di dalam proses NPD telah digunakan mulai dari perencanaan, desain-rekayasa, implementasi, dan manajemen proyek.

Namun demikian, Barzcak, Sultan, dan Hultink (2007) menemukan adanya kesenjangan antara ketersediaan berbagai perangkat IT di perusahaan dengan penggunaannya dalam proses NPD dan melakukan penelitian berjudul Determinants of IT Usage and New Product Performance. Penelitian tersebut bermaksud mengisi kekosongan kajian mengenai bagaimana dampak penggunaan perangkat IT bagi proyek NPD.

Pemanfaatan IT dalam pengembangan kualitas daya saing perindustrian di Indonesia merupakan prioritas pemerintah. Pemerintah Indonesia belum lama telah memperbaharui landasan hukum mengenai perindustrian dari Undang-Undang No. 5 tahun 1984 menjadi Undang-Undang No. 3 tahun 2014. Perubahan undang-undang tersebut merupakan upaya pemerintah untuk mendorong tingkat daya saing industri baik di arena nasional, regional, maupun global. Selain itu, pemerintah Indonesia pun menekankan pemanfaatan IT untuk kepentingan pengembangan perekonomian nasional melalui UndangUndang No. 11 tahun 2008 tentang Informasi dan Transaksi Elektronik.

World Bank melaporkan Indonesia masih berada pada urutan ke-77 dari 177 negara dalam hal indeks pengembangan teknologi informasi dan komunikasi. Sementara itu, The Economist Intelligence Unit (2011) meluncurkan IT Industry Competitiveness Index 2011 yang menyebutkan bahwa Indonesia berada pada urutan ke-57 dari 66 negara dengan kelemahan terbesar pada aspek $R \& D$ environment dan $I T$ infrastructure. Pembaharuan undang-undang perindustrian oleh pemerintah Indonesia dilakukan untuk mengatasi pemanfaatan teknologi informasi dan komunikasi yang masih rendah. 
Penelitian ini merupakan replikasi penelitian yang telah dilakukan oleh Barczak, Sultan, dan Gultink (2007) dengan judul Determinants of IT Usage and New Product Performance. Penelitian tersebut bertujuan untuk mengidentifikasi faktor-faktor penentu penggunaan IT dan dampaknya pada kinerja New Product Development (NPD). Barczak, Sultan, dan Gultink melakukan survey kepada 1,371 anggota Product Development and Management Association (PDMA) di Amerika Serikat dan Kanada. Tingkat respon (response rate) yang dicapai pada penelitian tersebut sebesar $15.5 \%$ atau sebanyak 212 anggota yang berpartisipasi dalam penelitian.

Selain itu, penelitian ini juga berupaya mengisi kelangkaan penelitian tentang NPD di tanah air di mana pada dasarnya merupakan bentuk penelitian awal yang mencoba mengkaji pengaruh peran IT dalam membangun kapabilitas inovasi yang menghasilkan nilai bagi perusahaan pada umumnya dan proyek NPD pada khususnya.

\section{Rumusan Masalah}

Meningkatnya penggunaan perangkat IT di dalam berbagai aktivitas perusahaan di Indonesia dengan ragam variasi tingkat kompleksitas, proses NPD yang semakin sistematis, dan posisi strategis NPD sebagai salah satu komponen utama pembangun nilai perusahaan. Hal ini menyebabkan timbulnya persoalan seberapa jauh penggunaan IT dalam proses NPD dan dampak yang ditimbulkannya bagi keberhasilan proyek tersebut. Dengan demikian, rumusan masalah penelitian ini adalah sebagai berikut:

1. Apa faktor penentu penggunaan IT dalam proses NPD ?

2. Bagaimana dampaknya bagi kinerja proyek NPD?

\section{TINJAUAN TEORI DAN}

\section{PENGEMBANGAN HIPOTESIS}

Proses New Product Development (NPD) dan

\section{Penggunaan IT}

Cooper (2011) memperkenalkan model proses NPD yang disebut State-Gate ${ }^{\circledR}$ model. Model tersebut terdiri dari 5 tahap yang merentang dari peneluran ide sampai dengan peluncuran produk ke pasar. Di antara tiap tahapan proses terdapat gate yang berfungsi melakukan screening. Hal penting lainnya pada model ini adalah perhatian kepada suara konsumen di setiap tahapannya. 
Secara keseluruhan model State-Gate ${ }^{\circledR}$ dapat dibagi ke dalam tiga tahapan besar, yaitu tahapan Fuzzy Front-End, DevelopmentTesting, dan Launching. Dimulai dengan pengumpulan ide yang akan dilanjutkan dengan gerbang pertama (gate-1) berupa penyaringan ide (ideas screening) yang kemudian dilanjutkan dengan tahap pertama (stage-1) pencakupan (scoping) berupa pengkajian ideide yang telah tersaring baik berkaitan dengan potensi pasar sampai dengan perkiraan tingkat resiko. Tahapan pertama tersebut dilanjutkan melalui gerbang kedua (gate-2) untuk disaring sebelum masuk ke tahapan kedua (stage-2) yaitu dilakukannya penelusuran dan persiapan kasus bisnis (business case preparation) untuk ide yang telah mampu melewati gerbang kedua. Ide yang telah dilakukan kasus bisnis lalu akan memasuki gerbang ketiga (gate-3) untuk disaring dan dilaksanakan pengambilan keputusan mengenai ide mana yang akan berlanjut kepala proses pengembangan produk (development) lebih lanjut (stage-3). Langkah selanjutnya adalah penyaringan pada gerbang keempat (gate-4) untuk dilakukan tinjauan akhir pengembangan produk baru. Produk yang telah dibangun dan lolos dari gerbang keempat akan melalui tahapan keempat (stage-4) yaitu pengetesan akhir dan validasi (testing and validation). Hasil dari tahapan keempat tersebut akan melakui penyaringan terakhir, yaitu gerbang kelima (gate-5) yaitu analisa pendahuluan komersialisasi bisnis. Setelah hal tersebut dilakukan, produk baru akan memasuki tahapan akhir yaitu tahapan kelima (stage-5) berupa produksi penuh dan peluncuran produk baru ke pasar. Setelah beberapa waktu yang telah ditentukan maka perlu dilakukan tinjauan ulang implementasi hasil pengembangan produk baru tersebut di pasar.

Lebih lanjut Cooper (2011) menemukan tujuh faktor kritikal yang membuat proses NPD mencapai kesuksesan, sebagai berikut :

1. Keunikan produk

2. Suara konsumen

3. Kesuksesan tahapan kritikal: tahapan front-end

4. Tajam dalam mendefinisikan proyek dan tahapan awal produk (termasuk menghindari cakupan proyek yang tidak tepat dan ketidakstabilan spesifikasi)

5. Proses pengembangan spiral yang melibatkan konsumen dari awal sampai akhir proses 
6. Ide yang baik pada tahapan eksekusi peluncuran produk baru

7. Kecepatan proyek NPD tanpa mengorbankan kualitas eksekusi.

Cooper (2011) menemukan 2/3 dari perusahaan dengan kinerja terbaik dalam melakukan proses inovasi merupakan perusahaan yang memiliki support dari sistem IT. Salah satu pengalaman terbaik penggunaan sistem IT adalah penerapannya pada central shared-information system yang merupakan sentralisasi komunikasi proyek di mana anggota tim proyek NPD saling berkomunikasi dan bertukar informasi antar fungsi, lokasi, bahkan antar negara.

Basis State-Gate ${ }^{\circledR}$ model yang melibatkan suara konsumen (voice of consumers/VoC) semakin memungkinkan dan berkembang di masa sekarang karena kemajuan perangkat IT, termasuk internet di dalamnya (Cooper, 2011). Pada tahap besar fuzzy frontend, pelanggan atau pengguna diundang untuk berkontribusi dalam pengembangan produk dan ide-ide produk baru selanjutnya (Cooper, 2011). Tahap development-testing, disampaikan Marion, Barczak, dan Hultink (2014) bahwa secara historikal tahap ini menggunakan perangkat IT dengan sangat intens, diawali dengan berbagai aktivitas perancangan produk seperti penggunaan CAD maupun manajemen proyek. Tahap launching, salah satu prinsip utama perencanaan peluncuran adalah prinsip proses iteratif di mana perencanaan, misalnya pemasaran, bukanlah proses yang dibuat setelah tahap besar kedua selesai ataupun sesuatu yang dirancang pada tahap besar pertama. Akan tetapi, perencanaan tersebut merupakan proses yang iteratif di mana mengalami revisi, cek-ricek, ataupun berkembang sepanjang proses NPD (Cooper, 2011). Oleh karena itu, proses komunikasi dan penggunaan database menjadi intens pada tahap ini sehingga perangkat IT akan cukup dipergunakan pada proses ini.

Internet merupakan bagian penting dalam kategori penggunaan perangkat IT (IT tools usage) sebagaimana dinyatakan oleh Marion, Barczak, Hultink (2014) dan Barzcak, Sultan, Hultink (2007). Berdasarkan hasil penelitian Ozer (2002), internet sebagai salah satu bentuk perangkat IT, memiliki kemampuan untuk berperan dalam proses NPD sebagai pengumpul dan alat tukar-menukar informasi termasuk fasilitasi kolaborasi, upaya 
pemahaman pasar secara efektif, menyediakan berbagai macam ide dan fleksibel. Selanjutnya, peranan internet tersebut juga dapat meningkatkan kecepatan dan kualitas analisis bisnis, meningkatkan kecepatan dan kualitas testing-validasi, dan meningkatkan keefektifan serta keefisienan pengembangan produksi produk baru. Walaupun demikian, dampak internet di atas bisa berbeda karena sangat bergantung kepada produk dan kondisi organisasi.

Pengembangan produk baru dengan pendekatan inovasi terbuka (Open Innovation) menjadi suatu pendekatan inovasi yang sedang berkembang berkat perkembangan teknologi khususnya teknologi informasi dalam melakukan engagement. Pada pendekatan tersebut perusahaan melakukan proses insideout dan outside-in bagi ketiga tahapan besar proses inovasi (Cooper, 2011 dan Chesbrough, 2003). Kemampuan untuk mempeluas pasar dalam rangka eksploitasi inovasi menjadi lebih tinggi karena adanya pendekatan inovasi terbuka (Cheng, Huizingh, 2014 dan Chesbrough, 2003).

Resource-Based Theory dan Sumber Daya IT
Resource-Based Theory (RBT) pertama kali dipublikasikan pada tahun 1984 (Wernerfelt,1984; Barney dan Clark, 2007). Pada dasarnya RBT memandang keunggulan kompetitif (competitive advantage) dan kinerja yang unggul dari sebuah organisasi ditentukan oleh perbedaan atau ketidaksamaan kapabilitas yang dimiliki suatu organisasi dengan organisasi lainnya (distinctiveness capabilities) (Johson dan Scholes, 2008; Barney dan Clark,2007).

Maksud dari sumber daya (resources) dalam RBT adalah aset dan kapabilitas (Wernerfelt, 1984; Wade dan Hulland, 2004 dalam Marion, Barczak, Hultink, 2014). Sedangkan Johson dan Scholes (2008) menyatakan sumber daya merupakan gabungan dari aset fisik (tangible) dan non-fisik (intangible) yang dimiliki oleh perusahaan dimmana sumber daya tersebut memiliki kandungan kritikal yang berfungsi sebagai fondasi dari keunggulan kompetitif. Dilanjutkan oleh mereka, kapabilitas strategis (strategic capability) merupakan kombinasi sumber daya dan kompetensi yang dimiliki oleh sebuah organisasi untuk mampu bertahan (survive) dan mencapai kesejahteraan (prosper). 
Pada titik tersebut di atas, Barney dan Clark (2007) menyatakan IT dapat dipandang sebagai bentuk sumber daya yang dapat menjadi unsur pembentuk keunggulan kompetitif. Akan tetapi, terdapat perbedaan antara IT sebagai sumber daya penambah nilai (adding value) dengan IT sebagai sumber daya keunggulan kompetitif yang terus menerus (sustained competitive advantage) bagi perusahaan.

Ross, Beat, dan Goodhue (1996) menyebut yang termasuk dalam aset IT adalah fisik aset IT, platform teknikal, database, arsitektur, dan standar. Wade dan Hulland (2004) menyampaikan aset teknologi membuat perusahaan menjadi lebih bernilai dan dapat terhindar dari ancaman subtitusi dari produk atau bisnis baru. Dengan demikian, aset teknologi dapat menciptakan keungulan kompetitif.

Pada tataran pengembangan produk, dimana NPD merupakan salah satu bagian penting dari penciptaan nilai bagi perusahaan (Cooper, 2011), penggunaan perangkat IT (IT tools usage) mencakup penggunaan berbagai bentuk IT perusahaan baik perangkat keras (hardware) maupun lunak (software) yang dipergunakan dalam aktivitas-aktivitas kolaborasi-komunikasi antar anggota tim, perangkat khusus pengembangan produk, manajemen proyek, pengelolaan informasi dan pengetahuan, riset pasar-analisa (Barzcak, Sultan, dan Hultink, 2007).

Barney dan Clark (2007) menjelaskan atribut sumber daya IT yang akan menjadikannya sumber daya keunggulan kompetitif menerus bagi perusahaan adalah keterampilan manajerial IT (managerial IT skills) yang tidak hanya meliputi pembangunan infrastruktur dan penggunaan aplikasi IT tetapi kemampuan manajemen dalam membentuk pola pandang dan mengeksploitasi penggunaan IT untuk mendukung keseluruhan fungsi bisnis.

\section{Kajian Penelitian Terdahulu}

Beberapa penelitian terdahulu yang signifikan dan menjadi landasan penelitian ini dapat dilihat pada Tabel 1. 
Tabel 1.

Kajian Penelitian Terdahulu

\begin{tabular}{|c|c|c|c|}
\hline \\
\hline Nama Peneliti & Metodologi & Hasil Penelitian & Relevansi Penelitian \\
\hline $\begin{array}{l}\text { Sunarto, et al. } \\
(2014)\end{array}$ & $\begin{array}{l}\text { Studi kasus Universitas } \\
\text { Kristen Satya Wacana }\end{array}$ & $\begin{array}{l}\text { Pemanfaatan perangkat IT yang menyeluruh dalam membangun } \\
\text { pengelolaan virtual office }\end{array}$ & $\begin{array}{c}\text { Best practices pengoptimalan } \\
\text { pemanfaatan perangkat IT dalam } \\
\text { upaya meningkatkan nilai organisasi }\end{array}$ \\
\hline $\begin{array}{l}\text { Prihantina, et al. } \\
\text { (2011) }\end{array}$ & Kajian literatur & Analisis sintesis situasi IT Indonesia dan industri IT & $\begin{array}{l}\text { Penjelasan kondisi pemanfaatan IT di } \\
\text { Indonesia }\end{array}$ \\
\hline Aziz (2011) & $\begin{array}{l}\text { Kombinasi metode kualitatif } \\
\text { dan kuantitatif, wawancara } \\
\text { pimpinan puncak PT. Pos } \\
\text { Indonesia dan PT. JNE, } \\
\text { survey, } 240 \text { responden di } \\
\text { empat wilayah Indonesia }\end{array}$ & $\begin{array}{l}\text { Pemanfaatan IT dalam PT Pos Indonesia \& PT JNE termasuk didalamnya } \\
\text { NPD untuk menigkatkan pelayanannya. Kendala utama pemanfaatan } \\
\text { adalah infrastruktur dan sistem IT }\end{array}$ & $\begin{array}{l}\text { Best practices penggunaan perangkat } \\
\text { IT dalam upaya meningkatkan nilai } \\
\text { perusahaan }\end{array}$ \\
\hline $\begin{array}{l}\text { Barczak, Sultan, } \\
\text { dan Hultink } \\
(2007)\end{array}$ & $\begin{array}{l}\text { Survey } 212 \text { praktisi anggota } \\
\text { PDMA di U.S dan Kanada, } \\
\text { korelasional riset. }\end{array}$ & $\begin{array}{l}\text { Faktor penentu yang memberikan pengaruh positif terhadap penggunaan } \\
\text { perangkat IT adalah resiko proyek, eksistensi 'champion', dan } \\
\text { keterlekatan penggunaan IT. Dampak penggunaan IT pada kinerja NPD } \\
\text { tampak pada kinerja pasar tetapi tidak berdampak kepada kecepatan } \\
\text { peluncuran produk ke pasar }\end{array}$ & $\begin{array}{l}\text { Penelitian terdahulu mengenai faktor } \\
\text { penentu penggunaan IT dalam dan } \\
\text { dampaknya pada kinerja NPD }\end{array}$ \\
\hline $\begin{array}{l}\text { Marion, Barczak, } \\
\text { dan Hultink } \\
(2014)\end{array}$ & $\begin{array}{l}\text { Survey, } 198 \text { responden } \\
\text { praktisi yang terlibat dalam } \\
\text { NPD fase Developing/Testing } \\
\text { dari } 193 \text { perusahaan, } \\
\text { korelasional riset. }\end{array}$ & $\begin{array}{l}\text { Tradisional perangkat IT memiliki efek signifikan dan berdampak positif } \\
\text { terhadap hasil NPD. Perangkat IT terbaru seperti wikis proyek dan shared- } \\
\text { collaboration spaces juga memiliki peran signifikan sehingga berdampak } \\
\text { positif pada pembuatan prototipe/konsep dan evaluasi manajemen pada } \\
\text { tahap developing-testing }\end{array}$ & $\begin{array}{l}\text { Penggunaan perangkat IT dalam } \\
\text { proses NPD. }\end{array}$ \\
\hline $\begin{array}{l}\text { Teo dan Choo } \\
(2001)\end{array}$ & $\begin{array}{l}\text { Survey; } 129 \text { perusahaan; } \\
\text { CEO/Managing directors }\end{array}$ & $\begin{array}{l}\text { Peningkatan kualitas informasi melalui penggunaan internet sehingga } \\
\text { memberikan benefit strategis }\end{array}$ & Terkait dengan variabel resiko \\
\hline Grover (1993) & $\begin{array}{l}\text { Survey; } 216 \text { respon dari CIOs } \\
\text { dan Direktur IS perusahaan }\end{array}$ & $\begin{array}{l}\text { Manajemen agresif yang berani mengambil resiko secara positif terkait } \\
\text { dengan adoption. }\end{array}$ & \\
\hline Beath (1991) & Interview 15 IT 'champion’ & $\begin{array}{l}\text { IT 'champion' mempromosikan ide mereka secara aktif di dalam proses } \\
\text { internal melalui edukasi dan berbagai penjelasan. }\end{array}$ & Terkait dengan variabel eksistensi \\
\hline Grover (1993) & $\begin{array}{l}\text { Survey; } 216 \text { respon dari CIOs } \\
\text { dan Direktur IS perusahaan }\end{array}$ & $\begin{array}{l}\text { Eksistensi “champion' merupakan penentu utama sistem customer-based } \\
\text { interorganizational. }\end{array}$ & 'champion' \\
\hline Grover (1993) & $\begin{array}{l}\text { Survey; } 216 \text { respon dari CIOs } \\
\text { dan Direktur IS perusahaan }\end{array}$ & $\begin{array}{l}\text { Pengambilan keputusan melalui partisipasi secara positif berasosiasi } \\
\text { dengan adopsi dari sebuah interorganizational system. }\end{array}$ & \\
\hline $\begin{array}{l}\text { Moch dan Morse } \\
\text { (1977) }\end{array}$ & $\begin{array}{l}\text { Petugas admistrasi dan kepala } \\
\text { rumah sakit, studi } 12 \text { macam } \\
\text { inovasi yg telah dilakukan, } \\
489 \text { rumah sakit. }\end{array}$ & $\begin{array}{l}\text { Desentralisasi mempengaruhi adopsi inovasi yang dilakukan di rumah } \\
\text { sakit. Besarnya ukuran organisasi mempengaruhi dampak adopsi. }\end{array}$ & Terkait dengan variabel otonomi \\
\hline
\end{tabular}


Tabel 1. (Lanjutan)

\section{Kajian Penelitian Terdahulu}

\begin{tabular}{|c|c|c|c|}
\hline Nama Peneliti & Metodologi & Hasil Penelitian & Relevansi Penelitian \\
\hline $\begin{array}{l}\text { Cooper, Edgett, } \\
\text { dan Kleinschmidt } \\
(2004)\end{array}$ & $\begin{array}{l}\text { Kunjungan ke lokasi } 5 \\
\text { perusahaan, survey kepada } \\
105 \text { bisnis unit. }\end{array}$ & $\begin{array}{l}\text { Kinerja terbaik ditunjukkan oleh perusahaan yang memiliki iklim dan } \\
\text { budaya komunikasi terbuka. }\end{array}$ & \multirow[b]{2}{*}{$\begin{array}{l}\text { Terkait dengan variabel iklim inovasi } \\
\text { perusahaan }\end{array}$} \\
\hline $\begin{array}{l}\text { Armbrecht et al. } \\
(2001)\end{array}$ & $\begin{array}{l}\text { Interview semi-terstruktur } \\
\text { kepada eksekutif kunci yang } \\
\text { terlibat dengan manajemen- } \\
\text { pengetahuan di } 19 \text { perusahaan. }\end{array}$ & $\begin{array}{l}\text { Salah satu kunci pendorong dari manajemen-pengetahuan dalam R\&D } \\
\text { adalah budaya yang memberikan nilai kepada penciptaan dan }\end{array}$ & \\
\hline $\begin{array}{l}\text { Maidique dan } \\
\text { Zirger (1984) } \\
\text { Weill, Subramani, } \\
\text { dan Broadbent }\end{array}$ & $\begin{array}{l}\text { Dua survey kepada para } \\
\text { manajer perusahaan elektronik } \\
\text { U.S dilanjutkan dengan } 20 \\
\text { studi kasus mendalam (in- } \\
\text { depth case study). } 180 \mathrm{e}- \\
\text { business initiatives dalam } \\
\text { periode } 1990-2001 .\end{array}$ & $\begin{array}{l}\text { Perusahaan yang memiliki superioritas teknologi memiliki produk baru } \\
\text { yang lebih sukses dibanding perusahaan yang tidak memiliki kapabilitas } \\
\text { teknologi. Investasi dalam kapabilitas infrastruktur yang spesifik } \\
\text { dibutuhkan untuk mengimplementasikan bisnis inisiatif tertentu. Salah } \\
\text { satu klusternya adalah kapabilitas yang memfokuskan pada IT di area } \\
\text { R\&D, termasuk bagaimana bisnis menemukan cara-cara baru untuk } \\
\text { menggunakan IT dalam rangka menciptakan nilai bisnis. }\end{array}$ & \multirow[t]{2}{*}{$\begin{array}{c}\text { Terkait dengan variabel infrastruktur } \\
\text { IT }\end{array}$} \\
\hline $\begin{array}{l}\text { Anakwe, Igbaria, } \\
\text { dab Anandarajan } \\
(2000)\end{array}$ & $\begin{array}{l}170 \text { pekerja dari } 9 \text { organisasi } \\
\text { di Nigeria }\end{array}$ & $\begin{array}{l}\text { Dukungan organisasi secara positif terkait dengan penggunaan rutin } \\
\text { komputer dan frekuensi pengunaannya. Dukungan organisai merujuk } \\
\text { kepada sikap positif terhadap penggunaan mikro-komputer yang } \\
\text { diperkenalkan oleh manajemen senior melalui penyediaan pelatihan dan } \\
\text { dukungan konsultasi IT. }\end{array}$ & \\
\hline Thomke (2006) & $\begin{array}{l}72 \text { proyek mobil yang } \\
\text { diluncurkan antara tahun } \\
1980 \text { dengan } 1999\end{array}$ & $\begin{array}{l}\text { Perangkat IT terbaru meningkatkan kapasitas pemecahan masalah dan } \\
\text { produktifitas. } \\
\text { Untuk mendapatkan benefit dari perangkat IT terbaru, } \\
\text { Perusahaan harus mengintegrasikannya kedalam keseharian. }\end{array}$ & \multirow{2}{*}{$\begin{array}{l}\text { Terkait dengan variabel keterlekatan } \\
\text { penggunaan IT }\end{array}$} \\
\hline $\begin{array}{l}\text { Boynton, Zmud, } \\
\text { dan Jacobs (1994) }\end{array}$ & $\begin{array}{l}\text { Survey, } 132 \text { perusahaan, } \\
\text { eksekutif IT senior. }\end{array}$ & $\begin{array}{l}\text { Pengetahuan mengenai IT memfasilitasi pertukaran informasi dan } \\
\text { pemecahan masalah bersama sehingga organisasi mampu menggunakan } \\
\text { IT untuk meningkatkan nilai bisnis ke tataran yang lebih tinggi. } \\
\text { Mendorong pengambilan keputusan berkontribusi kepada pengetahuan IT. }\end{array}$ & \\
\hline $\begin{array}{l}\text { Durmusoglu, } \\
\text { Calantone, dan } \\
\text { Sambarmurthy } \\
(2006)\end{array}$ & $\begin{array}{l}\text { Mail Survey, } 21 \text { dyads pada } \\
\text { Kepada Departemen IT dan } \\
\text { pimpinan tim NPD. }\end{array}$ & $\begin{array}{l}\text { Baik rendah maupun tingginya frekuensi penggunaan IT diasosiakan } \\
\text { dengan biaya, kecepatan, atau fleksibilitas NPD. Tingginya penggunaan } \\
\text { IT diasosiasikan dengan rendahnya kualitas produk batu dan sebaliknya. }\end{array}$ & \multirow{3}{*}{$\begin{array}{l}\text { Terkait dengan variabel penggunaan } \\
\text { IT dan kinerja. }\end{array}$} \\
\hline $\begin{array}{l}\text { Osei-Bryson dan } \\
\text { Ko (2004) }\end{array}$ & $\begin{array}{l}\text { Data tersedia dari } \\
\text { Brynjolfsson dan Hitt. }\end{array}$ & $\begin{array}{l}\text { Investasi dalam IT harus melewati suatu nilai minimum tertentu sebelum } \\
\text { memberikan dampak positif kepada produktifitas. }\end{array}$ & \\
\hline $\begin{array}{l}\text { Devaraj dan } \\
\text { Kohli (2003) }\end{array}$ & $\begin{array}{l}8 \text { rumah sakit, selama periode } \\
36 \text { bulan. }\end{array}$ & $\begin{array}{l}\text { Penggunaan IT secara positif berasosiasi dengan pendapatan dan kualitas } \\
\text { rumah sakit. }\end{array}$ & \\
\hline
\end{tabular}




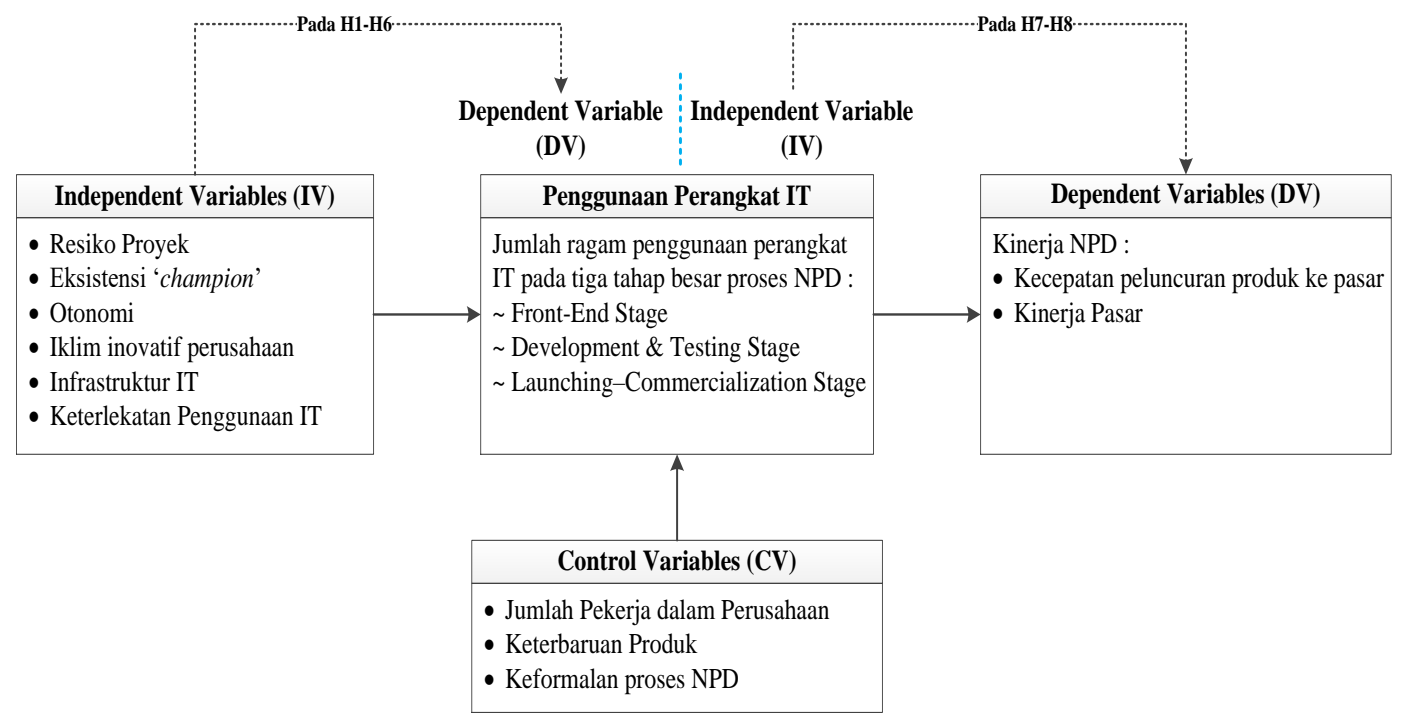

Gambar 1.

Kerangka Konseptual

Sumber : Adaptasi dan modifikasi atas Barzcak, Sultan, dan Hultink (2007)

\section{Kerangka Konseptual}

Penelitian ini menggunakan kerangka

konseptual yang sama dengan penelitian

Barzcak, Sultan, dan Hultink (2007). Beberapa

tambahan visualisasi untuk lebih memperjelas

kerangka pemikiran konsep telah dilakukan

dalam penelitian ini tertera dalam gambar 1 .

\section{Hipotesis}

Hipotesis dalam penelitian ini menggunakan hipotesis yang sama dengan penelitian Barzcak, Sultan, dan Hultink (2007). Hipotesis-hipotesis tersebut dijabarkan seperti berikut:

Tabel 2.

Hipotesis

\begin{tabular}{|l|l|}
\hline No & \multicolumn{1}{|c|}{ Hipotesis } \\
\hline H1 & Makin tinggi resiko produk yang dikembangkan, semakin tinggi penggunaan IT dalam proyek NPD. \\
\hline H2 & $\begin{array}{l}\text { Semakin besar keberadaan seorang 'champion' dalam penggunaan perangkat spesifik IT, semakin } \\
\text { tinggi penggunaan IT dalam proyek NPD. }\end{array}$ \\
\hline H3 & Semakin besar otonomi sebuah tim, semakin tinggi penggunaan. \\
\hline H4 & $\begin{array}{l}\text { Semakin tinggi suasana/iklim inovatif sebuah perusahaan, semakin tinggi penggunaan IT dalam } \\
\text { proyek NPD. }\end{array}$ \\
\hline H5 & $\begin{array}{l}\text { Semakin tinggi tingkat kemajuan/kecanggihan infrastruktur IT dan semakin besar dukungan } \\
\text { penggunaan perangkat IT, semakin tinggi pengunaan IT dalam proyek NPD. }\end{array}$ \\
\hline H6 & $\begin{array}{l}\text { Semakin tinggi keterlekatan IT dalam sebuah perusahaan, semakin tinggi penggunaan IT dalam } \\
\text { proyek NPD. }\end{array}$ \\
\hline H7 & $\begin{array}{l}\text { Semakin tinggi penggunaan perangkat IT sepanjang proyek NPD, semakin tinggi peningkatan } \\
\text { kecepatan keberadaan produk di pasar }\end{array}$ \\
\hline H8 & $\begin{array}{l}\text { Semakin besar penggunaan perangkat IT sepanjang proyek NPD, semakin besar dorongan kinerja } \\
\text { pasar. }\end{array}$ \\
\hline
\end{tabular}




\section{Definisi Operasional}

Berikut adalah beberapa definisi yang akan digunakan dalam penelitian replikasi ini:

- Tiga tahapan utama NPD adalah mencakup tahapan pertama, peneluran ide s/d simulasi bisnis; tahapan kedua, development-testing; tahapan ketiga, peluncuran-komersialisasi.

- Perangkat IT (IT tools) adalah penggunaan berbagai bentuk IT perusahaan baik hardware maupun software yang dipergunakan dalam aktivitas-aktivitas kolaborasi komunikasi antar anggota tim, perangkat khusus pengembangan produk, manajemen proyek, pengelolaan informasi dan pengetahuan, riset pasaranalisa.

- Resiko proyek adalah ketidakpastian mengenai masa depan sebuah proyek dan berkaitan dengan besarnya potensi kegagalan.

- Eksistensi individu "champion" adalah keberadaan individu yang secara antusias, memiliki komitmen dan memegang peranan penting dalam mempromosikan penggunaan perangkat IT pada proses NPD.

- Otonomi adalah tingkat kebebasan sebuah tim proyek dalam mengambil keputusan.

- Iklim inovatif perusahaan adalah tingkat suasana dimana organisasi mendukung kreatifitas pekerja dan toleran terhadap perbedaan pemikiran serta perspektif.

- Keterlekatan penggunaan IT adalah sejauh mana perangkat IT dipergunakan secara rutin dalam proses NPD.

- Kinerja NPD adalah kinerja yang mencakup dua pengukuran, yaitu kecepatan peluncuran produk di pasar dan kinerja pasar.

- Kecepatan peluncuran produk di pasar adalah waktu proses yang dibutuhkan sejak dari peneluran ide sampai peluncuran produk ke Pasar.

- Kinerja pasar adalah kinerja sebuah produk baru dalam mencapai obyektif pemasaran yang berkenaan dengan pencapaian penjualan, pangsa pasar, profitabilitas, dan kepuasan konsumen. 


\section{METODE RISET}

Penelitian ini dilakukan pada perusahaan-perusahaan menengah dan besar yang berdomisili di wilayah Jakarta, Bogor, Depok, Tangerang, dan Bekasi (Jabodetabek) pada Febuari sampai dengan Juni 2015. Penelitian yang merupakan replikasi dari Determinants of IT Usage and New Product Performance (Barczak, Sultan, dan Gultink, 2007) menggunakan pendekatan kuantitatif dengan rancangan konklusif bertipe single cross-sectional design. Pengukuran regresi berganda (multiple regresion) digunakan dalam mencari pola keterkaitan antar variabel dan korelasional antar variabel.

Unit analisa penelitian ini adalah proyek NPD yang dilakukan oleh perusahaan menengah (omzet per tahun Rp. 2,5 milyarRp. 50 milyar) dan besar (di atas Rp. 50 milyar).

Proyek NPD tersebut dilakukan dalam lima tahun terahir yaitu tahun 2010 sampai dengan tahun 2014.

Kriteria sumber data penelitian adalah keterlibatan seorang praktisi perusahaan pada satu tahapan tertentu ataupun keseluruhan tahapan proses NPD. Tiga tahapan utama NPD adalah pertama, peneluran ide s/d simulasi bisnis; kedua, development-testing; dan ketiga, peluncuran-komersialisasi. Dengan demikian, praktisi yang menjadi sumber data penelitian akan mencakup berbagai latar belakang fungsional mulai dari pemasaran, produksi, riset-pengembangan, dan lain-lain. Selain itu cakupan juga berkenaan dengan jenjang hirarki dalam organisasi perusahaan, mulai dari staff, asisten manager, manager, dan direktur. Instrumen penelitian yang digunakan adalah skrip wawancara terpandu (studi pendahuluan), kuesioner, program statistik SPSS, Microsoft office, dan perlengkapan pendukung seperti tape recorder.

\section{Teknik Pengumpulan Data dan Informasi}

Penelitian ini menerapkan studi pendahuluan (preliminary study) melalui wawancara untuk melakukan pemeriksaan atas beberapa variabel penting terkait dengan penggunaan IT dalam proses NPD. Dua narasumber praktisi dari industri confectioneries dan dari industri perbankan. Kedua sumber tersebut telah sesuai dengan kriteria narasumber.

Pengumpulan data primer dilakukan dengan metode survey melalui penyebaran kuesioner kepada target responden. Desain pengambilan sampel (sampling design) yang digunakan dalam penelitian adalah probability 
sampling dengan tipe simple random sampling.

Responden dipilih secara random dan tiap responden memiliki kesempatan lebih dari satu kali untuk dilakukan penarikan sampel. Hal ini berkaitan dengan tipe NPD yang telah ataupun sedang berlangsung di perusahaan tertentu selama lima tahun terakhir memiliki dua kemungkinan tipe. Produk baru yang dibangun dengan tipe improvement seperti penambahan varian, packaging baru, dan selanjutnya maupun produk baru yang bertipe trully new product, produk benar-benar baru yang tidak ada atau tidak dimiliki sebelumnya. Jika seorang responden mengalami kedua tipe NPD tersebut maka dapat dilakukan dua kali pengambilan sampel dimana yang pertama mengenai pengalaman keterlibatannya dalam proses NPD bertipe improvement dan kemudian dalam proses yang bertipe trully new product.

Jumlah responden ditentukan dengan menggunakan pendekatan Hair, Black, Babin dan Anderson (2010) di mana rasio antara banyaknya observasi yang harus dilakukan tiap variabel independen sebaiknya tidak boleh dibawah 5 : 1 dan dilakukan sekitar 15-20 observasi. Penelitian ini menggunakan delapan variabel independen sehingga diharapkan terdapat minimum 40 observasi ( 8 variabel x 5 observasi $=40$ observasi).

Karena tingkat kesulitan pengumpulan data cukup tinggi (kriteria responden yang cukup spesifik dan tingkat dropping valid sample yang cukup tinggi 50\%-60), maka penelitian dilakukan pada target mencapai rasio mínimum. Hasil dari pengumpulan data didapat sampel valid sebanyak 83 observasi/sampel. Jumlah sampel tersebut sudah melebihi syarat minimun yang disarankan oleh pendekatan Hair, Black, Babin dan Anderson (2010) yaitu minimum 40 observasi untuk delapan variabel independen.

\section{Teknik Pengolahan dan Analisis Data}

Multi-korelasi dan multi regresi dilakukan untuk menentukan faktor penentu apa yang memiliki tingkat keterkaitan dan kekuatan pengaruh penggunaan perangkat IT sepanjang proses NPD. Pengolahan data penelitian dilakukan dalam dua tahap:

1. Tahap Pertama $\rightarrow$ menguji faktor penentu penggunaan IT terhadap penggunaan perangkat IT pada proses NPD. Variabel bebas (independent variable/IV) terdiri dari resiko proyek, eksitensi 'champion', otonomi tim, iklim inovatif perusahaan, 
Penggunaan IT dalam Proyek New... (Boy Bayu I, Pepey Riawati K \& Siti Nuraisyah S)

infrastruktur IT, dan keterlekatan

penggunaan IT. Variabel terikat

(dependent variable/DV) adalah

penggunaan perangkat IT dalam

berbagai aktivitas sepanjang proses

NPD.

2. Tahap kedua $\rightarrow$ mempelajari dampak dari penggunaan perangkat IT terhadap kinerja proyek NPD. Variabel bebas (independent variable/IV) adalah penggunaan perangkat IT sepanjang proses NPD sedangkan variabel terikat (dependent variable/DV) adalah kecepatan peluncuran produk ke pasar dan kinerja pasar yang menggambarkan kinerja proyek NPD.

\section{Karakteristik Sampel}

Karakteristik sampel yang dapat diidentifikasi adalah jenis industri, omzet ratarata/tahun, jumlah pekerja tetap, dan fungsi responden. Empat karakter tersebut dapat dilihat pada Tabel 3. Dari karakteristik sampel dapat dilihat bahwa responden telah sesuai dengan kriteria. Terdapat pula beberapa perusahaan responden yang telah memiliki fungsi khusus untuk menangani NPD.

Dalam lima tahun terakhir, karakteristik dari tipe NPD yang dilakukan di perusahaan responden adalah peningkatan produk/product improvent $(52,5 \%)$ dibanding tipe produk yang benar-benar baru dipasarkan/truly new product $(23,8 \%)$. Selain itu, sebanyak $64,6 \%$ responden melakukan NPD dengan pola format bertingkat (seperti pembentukan tim proyek, mulai dari tahapan ide sampai komersialisasi).

\section{PEMBAHASAN}

\section{Matriks Korelasi}

Hampir keseluruhan faktor penentu memiliki hubungan yang positif dan cukup signifikan dalam rentang $\mathrm{r}=0.229-0.505$ baik pada $\alpha<0.01$ dan $\alpha<0.05$. Hanya hubungan faktor penentu iklim inovatif dengan eksistensi individu 'champion' dan infrastruktur IT dengan otonomi yang tidak memiliki hubungan signifikan baik pada tingkat kepercayaan $\alpha$ $<0.01$ maupun $\alpha<0.05$. Hasil tersebut juga ditunjukkan oleh penelitian Barczak, Sultan, dan Hultink (2007) sebelumnya di mana faktor penentu 'champion' dengan otonomi tidak memiliki hubungan yang signifikan.

Hubungan yang sangat positif dan sangat signifikan ditunjukkan antara faktor penentu iklim inovatif perusahaan dengan faktor penentu otonomi $(r=0.505$ pada $\alpha<0.01)$. 
Tabel 3.

Karakteristik Sampel

\begin{tabular}{|c|c|c|c|c|c|c|c|}
\hline \multicolumn{2}{|l|}{ Industri } & \multicolumn{2}{|c|}{$\begin{array}{l}\text { Omzet rata- } \\
\text { rata/tahun }\end{array}$} & \multicolumn{2}{|c|}{$\begin{array}{c}\text { Jumlah pekerja } \\
\text { tetap }\end{array}$} & \multicolumn{2}{|c|}{ Fungsi responden } \\
\hline $\begin{array}{l}\text { Baby Milk \& Diary } \\
\text { Product }\end{array}$ & $1,2 \%$ & $\begin{array}{l}<\text { Rp. } 2,5 \\
\text { milyar }\end{array}$ & $4,9 \%$ & $\begin{array}{l}<100 \\
\text { orang }\end{array}$ & $26,3 \%$ & Pemasaran & $30,5 \%$ \\
\hline $\begin{array}{l}\text { Food Processing, } \\
\text { beverages \& } \\
\text { confectioneries }\end{array}$ & $12,0 \%$ & $\begin{array}{l}\text { Rp. } 2,5- \\
25 \text { milyar }\end{array}$ & $28,4 \%$ & $\begin{array}{l}100-349 \\
\text { orang }\end{array}$ & $20,0 \%$ & $\begin{array}{l}\text { Riset dan } \\
\text { pengembangan }\end{array}$ & $23,2 \%$ \\
\hline $\begin{array}{l}\text { Pharmaceutical \& } \\
\text { Personal Care }\end{array}$ & $25,3 \%$ & $\begin{array}{l}\text { Rp. } 25,1- \\
50 \text { milyar }\end{array}$ & $9,9 \%$ & $\begin{array}{l}350-699 \\
\text { orang }\end{array}$ & $15,0 \%$ & Poduksi/manufaktur & $4,9 \%$ \\
\hline $\begin{array}{l}\text { Telecommunication } \\
\& \text { IT Provider }\end{array}$ & $13,3 \%$ & $\begin{array}{l}>\text { Rp. } 50 \\
\text { milyar }\end{array}$ & $56,8 \%$ & $\begin{array}{l}700-949 \\
\text { orang }\end{array}$ & $11,3 \%$ & Engineering & $3,7 \%$ \\
\hline $\begin{array}{l}\text { Finance, Banking \& } \\
\text { Insurance }\end{array}$ & $3,6 \%$ & & & $\begin{array}{l}950- \\
1190 \\
\text { orang }\end{array}$ & $3,8 \%$ & Teknologi informasi & $1,2 \%$ \\
\hline $\begin{array}{l}\text { Electronic \& } \\
\text { Computer }\end{array}$ & $2,4 \%$ & & & $\begin{array}{l}>1200 \\
\text { orang }\end{array}$ & $23,8 \%$ & Direktur & $11,0 \%$ \\
\hline $\begin{array}{l}\text { Automotive \& } \\
\text { automotive } \\
\text { accessories } \\
\text { manufacturing }\end{array}$ & $2,4 \%$ & & & & & $\begin{array}{l}\text { Lain-lain : Finance, } \\
\text { NDP-Business } \\
\text { Development, } \\
\text { strategic planning, dll }\end{array}$ & $25,6 \%$ \\
\hline $\begin{array}{l}\text { Industry lain-lain, } \\
\text { termasuk campuran } \\
\text { industry (perusahaan } \\
\text { terlibat dengan } \\
\text { beberapa macam } \\
\text { industry sekaligus) }\end{array}$ & $39,8 \%$ & & & & & & \\
\hline
\end{tabular}

Sumber : Hasil olah data

Tabel 4.

Tipe dan Proses NPD yang Digunakan di Perusahaan Responden

\begin{tabular}{|c|c|c|c|}
\hline \multicolumn{2}{|c|}{ Tipe NPD yang dilakukan } & \multicolumn{2}{|c|}{$\begin{array}{l}\text { Proses NPD } \\
\text { gunakan tahapan } \\
\text { format bertingkat }\end{array}$} \\
\hline $\begin{array}{l}\text { Produk baru tipe } \\
\text { improvement }\end{array}$ & $52.5 \%$ & $\mathrm{Ya}$ & $64.6 \%$ \\
\hline $\begin{array}{l}\text { Produk } \\
\text { Improvement \& } \\
\text { Trully New } \\
\text { Product }\end{array}$ & $23.8 \%$ & Tidak & $35.4 \%$ \\
\hline \multirow[t]{2}{*}{$\begin{array}{l}\text { Produk baru tipe } \\
\text { Trully New } \\
\text { Product }\end{array}$} & $23.8 \%$ & & \\
\hline & $100 \%$ & & $100 \%$ \\
\hline
\end{tabular}

Sumber: Hasil olah data

Sebagaimana otonomi merupakan

tingkat kebebasan sebuah tim proyek dalam mengambil keputusan NPD, maka iklim inovatif dalam perusahaan akan sangat berkorelasi kuat dengan berjalannya hal tersebut. Disampaikan oleh Grover (1993) upaya organisasi menerapkan inovasi akan terhambat ketika pendekatan terpusat (highcentralization) tim proyek memiliki sedikit otonomi. Dipertegas oleh Cooper, Edgett, dan Kleinschmidt (2004) serta Siegel dan Kaemmerer (1978) bahwa otonomi dalam ruang iklim inovatif organisasi tersebut akan mendorong tim proyek mengembangkan kreativitas untuk mencoba dan menemukan sesuatu yang baru serta meningkatkan 
komuniskasi yang terbuka antar tim proyek yang terdiri dari beragam fungsi.

Selain itu, hubungan antara faktor penentu infrastruktur IT dan penentu keterlekatan penggunaan IT dengan iklim inovatif (berturut-turut $r=0.458, r=0.350 \mathrm{pada}$ $\alpha<0.01)$ menunjukkan hubungan positif yang signifikan. Hal ini menggambarkan iklim inovatif yang sarat dengan interaksi lintas fungsi membutuhkan suatu sarana pendukung yang bisa didapat dalam infrastruktur IT. Seperti temuan Sambarmurthy dan Zmud (2000, dalam Barczak, Sultan, dan Hultink, 2007) yang menyebutkan infrastruktur IT memfasilitasi proses lintas fungsi dalam organisasi.

Faktor penentu infrastruktur IT dan keterlekatan peggunaan IT memiliki hubungan yang cukup signifikan dengan faktor penentu eksistensi individu 'champion' (berturut-turut $r=0.323, r=0.401$ pada $\alpha<0.01)$. Keadaan ini sesuai dengan penelitian sebelumnya dari Grover (1993) dan Beath (1991) yang menemukan adanya eksistensi 'champion' yang memainkan peran penting kepada impelmentasi suatu sistem IT. Sementara itu, hubungan antar faktor penentu lainnya masih mempunyai hubungan yang positif dalam tingkat kepercayaan yang lebih rendah $(\alpha$ $<0.05)$ seperti hubungan antara faktor penentu otonomi dan iklim inovatif dengan risiko proyek atau hubungan antara faktor penentu infrastruktur IT dan keterlekatan penggunaan IT dengan risiko proyek. Matriks korelasi dapat dilihat pada tabel 5 .

Hasil ini sedikit berbeda dengan temuan dalam penelitian Barczak, Sultan, dan Hultink (2007) sebelumnya yang menunjukan hubungan positif dan signifikan dengan tingkat kepercayaan $\alpha<0.01$ pada hubungan antara faktor penentu eksistensi individu 'champion' $(r=0.23)$, keterlekatan penggunaan IT $(r=0.44)$, otonomi, $(r=0.22)$ dan iklim inovatif $(r=0.21)$ dengan infrastruktur IT. Juga antara faktor penentu otonomi $(\mathrm{r}=0.38)$ dan keterlekatan penggunaan IT $(r=0.24)$ dengan iklim inovatif. Kesamaan hubungan yang signifikan seperti hal tersebut juga ditunjukkan hubungan antara faktor penentu eksistensi 'champion' ( $\mathrm{r}=0.27)$ dan risiko $(\mathrm{r}=0.19)$ proyek dengan keterlekatan penggunaan IT. 
Tabel 5.

\begin{tabular}{|c|c|c|c|c|c|c|c|c|c|}
\hline \multicolumn{10}{|c|}{ Matriks Korelasi dan Statistik Deskriptif } \\
\hline Variabel & $\begin{array}{c}\text { Perangkat IT } \\
\text { dalam } \\
\text { berbagai } \\
\text { aktivitas (IT } \\
\text { Usage) }\end{array}$ & $\begin{array}{l}\text { Faktor } \\
\text { penentu } \\
\text { resiko } \\
\text { proyek } \\
\text { (Project } \\
\text { Risk) }\end{array}$ & $\begin{array}{l}\text { Faktor penentu } \\
\text { eksistensi } \\
\text { individu } \\
\text { 'champion' } \\
\text { (exisence of } \\
\text { champion) }\end{array}$ & $\begin{array}{c}\text { Faktor } \\
\text { penentu } \\
\text { otonomi } \\
\text { (autonomy) }\end{array}$ & $\begin{array}{c}\text { Faktor } \\
\text { penentu iklim } \\
\text { inovatif } \\
\text { (innovative } \\
\text { climate) }\end{array}$ & $\begin{array}{c}\text { Faktor } \\
\text { penentu } \\
\text { infrastruktur } \\
\text { IT (IT } \\
\text { infrastructure) }\end{array}$ & $\begin{array}{c}\text { Faktor penentu } \\
\text { keterlekatan } \\
\text { penggunaan IT } \\
\text { (IT } \\
\text { Embeddedness) }\end{array}$ & $\begin{array}{l}\text { Dampak pada } \\
\text { kecepatan } \\
\text { peluncuran } \\
\text { produk ke } \\
\text { pasar (speed to } \\
\text { market) }\end{array}$ & $\begin{array}{c}\text { Dampak pada } \\
\text { kinerja pasar } \\
\text { (market } \\
\text { performance) }\end{array}$ \\
\hline \multicolumn{10}{|l|}{$\begin{array}{lcr}\text { Perangkat } & \text { IT } & \text { dalam } \\
\text { berbagai } & \text { aktivitas } & \text { (IT } \\
\text { usage) } & & \\
\end{array}$} \\
\hline $\begin{array}{l}\text { Faktor penentu resiko } \\
\text { proyek (Project Risk) }\end{array}$ & $.287(* *)$ & & & & & & & & \\
\hline $\begin{array}{l}\text { Faktor penentu eksistensi } \\
\text { individu 'champion' } \\
\text { (exisence of champion) }\end{array}$ & $.231(*)$ & $.229(*)$ & & & & & & & \\
\hline $\begin{array}{l}\text { Faktor penentu otonomi } \\
\text { (autonomy) }\end{array}$ & $.257(*)$ & $.266(*)$ & $.230(*)$ & & & & & & \\
\hline $\begin{array}{lr}\text { Faktor penentu iklim } \\
\text { inovatif } \\
\text { climate) }\end{array}$ & $.368(* *)$ & $.235(*)$ & .169 & $.505(* *)$ & & & & & \\
\hline \begin{tabular}{lr} 
Faktor & \multicolumn{2}{r}{ penentu } \\
infrastruktur & IT $\quad$ (IT \\
infrastructure) &
\end{tabular} & $.292(* *)$ & $.239(*)$ & $.323(* *)$ & .175 & $.458(* *)$ & & & & \\
\hline $\begin{array}{l}\text { Faktor penentu } \\
\text { keterlekatan penggunaan } \\
\text { IT (IT Embeddedness) }\end{array}$ & $.440(* *)$ & $.243(*)$ & $.401(* *)$ & $.283(*)$ & $.350(* *)$ & $.332(* *)$ & & & \\
\hline $\begin{array}{l}\text { Dampak pada kecepatan } \\
\text { peluncuran produk ke } \\
\text { pasar (speed to market) }\end{array}$ & $.297(* *)$ & $.245\left(^{*}\right)$ & .080 & .163 & $.459(* *)$ & $.459(* *)$ & $.282(*)$ & & \\
\hline $\begin{array}{ll}\text { Dampak pada } & \begin{array}{l}\text { kinerja } \\
\text { pasar }\end{array} \\
\text { (market }\end{array}$ & .149 & -.049 & -.049 & .098 & $.309(* *)$ & $.256(*)$ & .141 & $.427(* *)$ & \\
\hline Rata-rata (mean) & 3,6780 & 3,9319 & 3,4115 & 3,6341 & 3,8524 & 3,6082 & 4,0938 & 3,4198 & 3,4852 \\
\hline Deviasi standar & 0,78563 & 0,69006 & 1,54405 & 0,83741 & 0,72098 & 0,99104 & 0,80384 & 0,78842 & 0,75447 \\
\hline
\end{tabular}




\section{Penentu Penggunaan IT dan Dampaknya pada Kinerja Proyek NPD}

Hasil pengukuran model regresi pertama dari kerangka konseptual menguji regresi delapan faktor penentu (variabel independen) dengan penggunaan IT (variabel dependen). Regresi tersebut menunjukkan keterlekatan penggunaan IT (koefisien regresi terstandarisasikan, $\left.\beta_{\mathrm{std}}=0.44, \alpha<0.01\right)$, iklim inovatif $\left(\beta_{\text {std }}=0.368, \alpha<0.01\right)$, infrastruktur IT $\left(\beta_{\text {std }}=0.292, \alpha<0.01\right)$, dan risiko proyek $\left(\beta_{\text {std }}\right.$ $=0.287, \alpha<0.01)$ memiliki hubungan yang positif dan cukup berpengaruh kepada penggunaan IT dalam NPD. Dengan demikian H1, H4, H5, dan H6 dapat diterima.

Penelitian ini menunjukkan dan mendukung hipotesis H6; semakin tinggi keterlekatan IT dalam sebuah perusahaan maka semakin tinggi penggunaan IT dalam proyek NPD. Sebagaimana yang disampaikan oleh Sethi, Pant dan Sethi (2003) perusahaan yang memiliki tingkat keterlekatan IT yang cukup tinggi sangat mungkin menggunakan perangkat IT terintegrasi dalam proses NPD.

Hasil penelitian juga mendukung hipotesis $\mathrm{H} 4$ yang menyebutkan bahwa semakin tinggi iklim inovasi sebuah perusahaan akan semakin tinggi penggunaan IT dalam proyek NPD. Ketika iklim inovasi membuka peluang menemukan hal-hal baru dan semakin terbuka serta tingginya lalu-lintas komunikasi antar anggota tim proyek lintas fungsi maka penggunaan IT akan semakin tinggi. Sesuai yang disampaikan oleh Barczak, Sultan, dan Hultink (2007) bahwa dorongan untuk menemukan hal yang baru, pemecahan masalah, dan mencapai produktivitas dapat membuat pengguanaan IT dalam NPD menjadi tinggi.

Hipotesis H5 dimana semakin tinggi tingkat kemajuan/kecanggihan infrastruktur IT dan semakin besar dukungan penggunaan perangkat IT akan semakin tingginya pengunaan IT dalam proyek NPD, didukung oleh hasil penelitian ini. Hal ini menunjukan responden yang merupakan pihak-pihak yang terlibat dalam NPD cukup memberikan perhatian kepada keberadaan infrastruktur IT dalam kaitannya dengan proyek NPD. Situasi tersebut juga ditunjukkan oleh penelitian sebelumnya Sambamurthy dan Zmud (2000) yang menyebutkan fasilitas infrastruktur IT meningkatkan konektivitas antar fungsi seperti dalam NPD.

Hipotesis H1, semakin tinggi risiko produk yang dikembangkan maka semakin 
tinggi penggunaan IT dalam proyek NPD, juga

telah didukung oleh hasil penelitian ini. Risiko proyek NPD mendorong penggunaan IT secara intensif untuk memastikan keseluruhan rangkaian yang diperlukan dalam proses pengembangan produk termasuk di dalamnya pengambilan keputusan yang efektif. Grover (1993) telah menyebutkan bahwa ketika manajemen organisasi secara agresif akan menentukan atau mengambil risiko finansial dan organisasi maka kemungkinan besar akan mengadopsi sistem IT.

Namun demikian dengan tingkat kepercayaan $\alpha<0.05$ faktor penentu otonomi masih bisa menampakkan pengaruhnya pada penggunaan IT dalam NPD. Hanya saja faktor penentu eksistensi individu 'champion' tidak tampak hubungan yang signifikan dan pengaruh kepada penggunaan IT dalam NPD. Dengan kata lain riset-riset sebelumnya mengenai kedua faktor penentu tersebut tidak cukup bisa menjelaskan alasan penggunaan IT dalam proyek NPD.

Hasil penelitian ini memiliki sedikit perbedaan dengan penelitian sebelumnya, Barczak, Sultan, Hultink (2007) yang menunjukkan penggunaan IT memiliki hubungan positif dan signifikan dengan faktor penentu risiko proyek (H1), eksistensi individu 'champion' (H2), dan keterlekatan penggunaan IT (H6). Perbedaan ini tentu saja menunjukkan kondisi geografi dan pola operasi berbeda yang dimiliki perusahaan. Perbedaan terletak pada H2 yaitu faktor pengaruh eksitensi individu 'champion'. Di Indonesia, khususnya di wilayah riset dilakukan yaitu Jabodetabek tampak sistem sudah tersedia di perusahaan sehingga keberadaan champion untuk menawarkan sesuatu yang baru tampak tidak terlalu memberikan pengaruh kepada penggunaan IT dalam proyek NPD. Hal ini sejalan dengan temuan hasil studi pendahuluan dimana narasumber menggambarkan sistem IT yang dipergunakan dalam NPD di perusahaannya sudah tersedia dan tidak memerlukan 'champion' untuk memperkenalkan sistem baru (wawancara, Mrs $\mathrm{X}$, perusahaan confectioneries, 28 Febuari 2015).

Kontrol variabel baik jumlah pekerja, tipe keterbaruan produk, dan proses formal NPD yang ditempuh tidak menujukkan sesuatu hubungan yang signifikan. Dengan demikian berapapun besarnya jumlah pekerja, tipe NPD 
Tabel 6.

Model Regresi 1: Faktor Penentu Penggunaan IT dalam NPD

\begin{tabular}{|l|l|}
\hline \multicolumn{1}{|c|}{ NPD } & \multicolumn{1}{|c|}{$\begin{array}{c}\text { Penggunaan IT } \\
\text { terstandarisasi) }\end{array}$} \\
\hline Risiko Proyek & $0,287^{* *}$ \\
\hline Eksistensi champion & 0,231 \\
\hline Otonomi & $0,114^{*}$ \\
\hline Iklim inovatif perusahaan & $0,368^{* *}$ \\
\hline Infrastruktur TI & $0,292^{* *}$ \\
\hline Keterlekatan Penggunaan IT & $0,440^{* *}$ \\
\hline Jumlah Pekerja & -0.163 \\
\hline Tipe keterbaruan Produk & -0.025 \\
\hline $\begin{array}{l}\text { Proses Formal yang } \\
\text { ditempuh }\end{array}$ & 0.232 \\
\hline $\mathrm{R}^{2}$ & 0.315 \\
\hline Adjusted $\mathrm{R}^{2}$ & 0.252 \\
\hline F-value (hitung) & 5.048 \\
\hline F-value (tabel) & 2,22 pada $\alpha=0.05$ \\
& 3,05 pada $\alpha=0.01$ \\
\hline
\end{tabular}

Sumber : hasil olah data

yang dikembangkan maupun proses NPD yang

ditempuh, perusahaan tetap akan menggunakan

perangkat IT dalam mendukung proyek NPD.

Dari perhitungan koefisien determinasi $\left(\mathrm{R}^{2}\right)$

tampak $31.5 \%$ faktor-faktor penentu tersebut dapat menjelaskan penggunaan IT dalam proyek NPD. Walaupun demikian masih ada sekitar $68.5 \%$ faktor-faktor lain yang belum diketahui yang mungkin mempengaruhi penggunaan IT dalam proyek NPD. Pengukuran F-value menujukkan model faktorfaktor penentu terhadap penggunaan IT sudah cukup baik dan dapat diterima untuk menjelaskan fenomena tersebut.

Pengukuran model regresi kedua mengukur dampak penggunaan IT kepada kinerja proyek NPD yang diukur melalui kecepatan peluncuran produk ke pasar dan kinerja pasar. Hasil penelitian menunjukkan hubungan positif dan signifikan kepada dampak kecepatan peluncuran produk ke pasar $\left(\beta_{\text {std }}=0.474\right.$ pada $\left.\alpha<0.01\right)$. Diperkuat dengan hasil pengukuran koefisien determinasi $\left(\mathrm{R}^{2}\right)$ hubungan antara penggunaan IT dengan kecepatan peluncuran produk ke pasar masih cukup dapat dijelaskan $22.5 \%$ walaupun masih ada $77.5 \%$ pengaruh variabel lain yang belum terjelaskan. Dari hasil F-Value terlihat model penggunaan IT terhadap kinerja NPD dalam hal kecepatan peluncuran produk ke pasar telah cukup baik dan dapat diterima. Hasil tersebut konsisten dengan penelitian-penelitian sebelumnya dari Bowden (2004), Sethi, Pant, dan Sethi (2003), Ozer (2000) yang menyebutkan penggunaan IT dapat meningkatkan kecepatan peluncuran produk di pasar.

Berbeda hasil dengan dampak penggunaan IT terhadap kinerja NPD dalam hal kinerja pasar. Hasil penelitian masih menujukkan hubungan yang signifikan tetapi dengan tingkat kepercayaan yang lebih rendah $\left(\beta_{\text {std }}=0.281\right.$ pada $\left.\alpha<0.05\right)$. Jika ditilik dari koefien determinasi $\left(\mathrm{R}^{2}\right)$ hubungan antara 
Tabel 7.

Model Regresi 2 dan 3: Dampak Penggunaan

IT terhadap NPD

\begin{tabular}{|c|c|c|}
\hline & $\begin{array}{c}\text { Model } \\
\text { Regresi 2 } \\
\end{array}$ & \begin{tabular}{|r|}
$\begin{array}{c}\text { Model } \\
\text { Regresi 3 }\end{array}$ \\
\end{tabular} \\
\hline & $\begin{array}{c}\text { Kecepatan } \\
\text { Peluncuran } \\
\text { Produk ke Pasar } \\
\text { (Speed to } \\
\text { Market }) \\
(\beta \\
\text { terstandarisasi) }\end{array}$ & $\begin{array}{c}\text { Kinerja } \\
\text { Pasar } \\
\text { (Market } \\
\text { Performance) } \\
(\beta \\
\text { terstandarisasi) }\end{array}$ \\
\hline $\begin{array}{l}\text { Penggunaan } \\
\text { IT (IT Usage) }\end{array}$ & $0,474 * *$ & $0,281^{*}$ \\
\hline $\mathrm{R}^{2}$ & 0.225 & 0.079 \\
\hline Adjusted $\mathrm{R}^{2}$ & 0.214 & 0.066 \\
\hline (hitung) & 20.591 & 6.008 \\
\hline (tabel) & \multicolumn{2}{|c|}{$\begin{array}{l}3,96 \text { pada } \alpha=0.05 \\
6,96 \text { pada } \alpha=0.01\end{array}$} \\
\hline
\end{tabular}

Sumber: Hasil olah data

penggunaan IT dengan kinerja pasar masih sangat rendah, hanya 7.9\%. Dipertegas dengan hasil pengukuran F-Value yang tidak memenuhi syarat atau dibawah dari F-Value (tabel). Dengan demikian, walaupun penggunaan IT menunjukkan tingkat signifikansi tetapi tidak cukup memberikan pengaruh kepada dampak kinerja pasar. Keadaan tersebut dapat diindikasikan oleh penelitian sebelumnya yang dilakukan oleh Osei-Bryson dan Ko (2004) bahwa adanya ketidak-konsistenan antara investasi di bidang IT dengan kinerja perusahaan. Indikasi lainnya adalah perusahaan lebih mengutamakan pencapaian efisiensi dalam proses NPD sehingga kecepatan peluncuran produk ke pasar lebih menunjukkan hasil yang cukup signifikan dalam penggunaan IT (Barczak, Sultan, Hultink, 2007). Berdasarkan studi pendahuluan juga menyatakan kinerja pasar NPD masih sulit dikaitkan dengan adanya penggunaan IT dalam proses proyek NPD (Wawancara, Mr. X, perusahaan perbankan, 25 Febuari 2015).

Hasil penelitian ini juga menunjukkan perbedaan dengan penelitian sebelumnya yang dilakukan oleh Barczak, Sultan, dan Hultink (2007) yang menunjukkan penggunaan IT dalam proyek NPD lebih berdampak kepada kinerja pasar dibanding kecepatan peluncuran produk di pasar. Juga ditunjukkan oleh Teo dan Choo (2001) serta Ozer (2000) pengunaan perangkat IT akan memberikan kualitas pengambilan keputusan terkait dengan produk baru. Pada kondisi penelitian tersebut, Barczak, Sultan, dan Hultink menduga tim proyek NPD memerlukan waktu yang lebih lama menyesuaikan diri maupun fungsi bidang kerja terhadap pengunaan berbagai perangkat IT terintegrasi dalam proyek NPD sehingga kinerja kecepatan peluncuran produk ke pasar tidak cukup signifikan dibanding kinerja pasar. 


\section{KESIMPULAN DAN SARAN}

\section{Kesimpulan}

Faktor anteseden terhadap penggunaan perangat IT yang memiliki hubungan positif dan cukup berpengaruh sehingga lebih menentukan penggunaan IT dalam NPD adalah variabel keterlekatan penggunaan IT, iklim inovatif, infrastruktur IT, dan resiko proyek. Sementara itu, dampak penggunaan IT kepada kinerja proyek lebih ditunjukan oleh variabel kecepatan peluncuran produk ke pasar melalui hubungan yang positif dan signifikan dibanding variabel kinerja pasar.

\section{Implikasi Manajerial}

Implikasi manajerial dari hasil penelitian ini adalah:

1. Perusahaan yang menitik-beratkan pencapaian efisiensi dalam proyek NPD akan lebih mendorong penggunaan IT yang berorientasi kepada kecepatan peluncuran produk ke pasar dibanding kinerja pasar.

2. Praktisi dapat memanfaatkan hasil penelitian berupa faktor-faktor yang berpengaruh pada penggunaan IT yaitu keterlekatan penggunaan IT, infrastruktur IT, iklim inovatif dan risiko proyek. Salah satu kunci keberhasilan suatu proyek NPD adalah bagaimana komunikasi dan pengambilan keputusan bisa berlangsung dengan sangat baik di dalam rangkaian proses NPD. Keterlekatan IT ini begitu penting dalam proyek NPD yang mencakup berbagai macam aktivitas yang cukup kompleks, seperti pada komunikasi lintas fungsi. Selain itu, sulit bagi perusahaan mengembangkan iklim inovatif di dalam proyek NPD tanpa keterlibatan fungsi penggunaan IT. Risiko proyek NPD pun dapat ditekan dengan dukungan penggunaan IT yang intensif dalam menilai pasar, konsumen, persaingan, komunikasi antar fungsi dan pengambilan keputusan.

3. Meski hasil penelitian ini menunjukkan faktor otonomi hanya memiliki signifikasi pada tingkat kepercayaan $\alpha=$ 0.05 dan keberadaan individu 'champion' tidak signifikan menentukan penggunaan IT dalam proyek NPD, keberadaannya tidak dapat diabaikan dalam aktivitas manajerial sehari-hari. Keberadaan 'champion' tetap penting untuk mendorong sebuah proses baru 
apalagi yang bersifat terobosan dalam perusahaan.

\section{Keterbatasan dan Penelitian Selanjutnya}

Pengembangan di penelitian selanjutnya diharapkan dapat bisa menjelaskan faktorfaktor lain sebesar $68.5 \%$ yang menentukan penggunaan IT dalam proyek NPD dan $77.5 \%$ faktor yang membuat perusahaan menengah dan besar di Indonesia lebih menekankan pada kecepatan peluncuran produk ke pasar dibanding kinerja pasar. Sebaran ragam industri di luar dari industri farmasi, perawatan tubuh, telekomunikasi dan penyedia layanan IT serta sebaran fungsi responden yang masih terkait dengan proyek NPD di luar dari fungsi pemasaran, riset-pengembangan, dan direksi akan mampu lebih menjelaskan fenomena tersebut. Selain itu, penelitian selanjutnya disarankan menggunakan pendekatan kuota sampling sehingga pola penggunaan IT dan dampaknya pada proyek NPD dapat tergambarkan lebih baik lagi.

Dampak penggunan IT dalam proyek NPD kepada kinerja pasar yang tidak cukup signifikan perlu di teliti lebih lanjut. Motivasi yang membuat perusahaan lebih cenderung berfokus kepada kecepatan peluncuran produk ke pasar dalam kaitannya dengan penggunaan
IT dalam proyek NPD dibanding kinerja pasar suatu hal yang cukup mengejutkan. Investasi IT dalam perusahaan patut diduga masih dianggap sebagai sistem pendukung yang belum dikaitkan dengan peningkatan kinerja perusahaan khususnya kinerja proyek NPD di pasar. Padahal Barney dan Clark (2007) telah mengingatkan adanya perbedaan IT sebagai sumber daya penambah nilai (added value) dengan IT sebagai sumber daya keunggulan kompetitif yang menerus (sustained competitive advantage) bagi perusahaan. 


\section{DAFTAR PUSTAKA}

Anakwe, U., Igbaria, M., and Anandarajan, M. (2000). Management Practices across Cultures: Role of Support in Technology Usage. Journal of International Business Studies 31(4):653-66.

Aziz, Azwar. (2012). Pemanfaatan Teknologi Informasi dalam Pengembangan Bisnis Pos. Buletin Pos dan Telekomunikasi 10 (1): 35-50

Armbrecht, F.M.R., Chapas, R.B., Chapelow, C.C., Farris, G.F.,Friga, P.N., Hartz, C.A., McIlvaine, M.E., Postle, S.R., and Whitwell, G.E. (2001). Knowledge Management in Research and Development. Research-Technology Management 44(4):28-49.

Barczak, G., Sultan, F., dan E.J. Hultink. (2007). Determinants of IT usage and new product development. Journal of Product Innovation Management 24: 600-613

Barney, Jay B. and Delwyn N. Clark. (2007). Resource-based theory: creating and sustaining competitive advantage. Oxford University Press. New York

Beath, C.M. (1991). Supporting the Information Technology Champion. MIS Quarterly 15(3):355-72.

Bowden, M. (2004). Report on the Role of IT in New Product Development Today. PDMA Visions 1:1-8 (January).

Boynton, A., Zmud, R., and Jacobs, G. (1994). The Influence of IT Management Practice on IT Use in Large Organizations. MIS Quarterly 18:299-318 (September).

Cheng, C. C., \& Huizingh, E. K. (2014). When is open innovation beneficial? The role of strategic orientation. Journal of product innovation management, 31(6), 1235-1253.

Chesbrough, Henry. (2003). Open Innovation: The new imperative for creating and profiting from technology. Harvard Business School Press. Massachussets

Cooper, Robert G. (2003). Winning at new products: creating value through innovation. Basic Books. New York

Cooper, R., Edgett, S., and Kleinschmidt, E. (2004). Benchmarking Best NPD Practice-I. Research Technology Management 47(1):31-41 (January-February).

Cooper, R. G. 2011. Winning at New Products: Creating Value Through Innovation, 4th ed. New York Basic Books-Perseus .

Devaraj, S. and Kohli, R. (2003). Performance Impacts of Information Technology: Is Actual Usage the Missing Link? Management Science 49(3):273-89.

Durmusoglu, S.S., Calantone, R.J., and V. Sambamurthy. (2006). Is more information technology better for new product development?. Journal of Product \& Brand Management 15 (7) 435-441

Farrell, D. (2003). The Real New Economy. Harvard Business Review 81(10):104-12.

Grover, V. (1993). An Empirically Derived Model for the Adoption of Customer-Based Interorganizational Systems. Decision Sciences 24(3):603-49.

Hair Jr, Joseph F., William C. Black., Barry J. Babin., Roldp E. Anderson. (2010). Multivariate Data Analysis (Seventh Edition). Pearson Eduction Limited. Essex

Johnson, G. and Scholes, K. (2008). Exploring corporate strategy (Eighth Edition). Pearson Eduction Limited. Essex

Maidique, M. and Zirger, B.J. (1984). A Study of Success and Failure in Product Innovation: The Case of the U.S. Electronics Industry. IEEE Transactions on Engineering Management 31(4):192-203.

Marion, T. J., Barczak, G., and E.J. Hultink. (2014). Do social media tools impact the development phase? An exploratory study. Journal of Product Innovation Management 31 (S1): 18-29

Moch, M.K. and Morse, E.V. (1977). Size, Centralization, and Organizational Adoption of Innovations. American Sociological Review 42(5):716-25.

Osei-Bryson, K.M. and Ko, M. (2004). Exploring the Relationship between Information Technology Investments and Firm Performance Using Regression Splines Analysis. Information and Management 42:1-13.

Ozer, M. (2002). Process implications of the use of the internet in new product development: A conceptual Analysis. Industrial Marketing Management 32: 517-530

Prihartina, Yun, dan kawan-kawan. (2011). Sistem Teknologi (Information Technology) Informasi di Indonesia. Program Studi Pascasarjana Teknik Industri. Universitas Gadjah Mada. Yogyakarta. 
Ross, J. W., C. M. Beath, and D. L. Goodhue. 1996. Develop long-term competitiveness through IT assets. Sloan Management Review 38 (1): 31-42.

Sambamurthy, V. and Zmud (2000). Research Commentary: The Organizing Logic for an Enterprises IT Activities in a Digital Era-A Prognosis of Practice and a Call for Research. Information Systems Research 11(2):105-14.

Sethi, R., Pant, S., and Sethi, A. (2003). Web-Based Product Development Systems Integration and New Product Outcomes: A Conceptual Framework. Journal of Product Innovation Management 20:37-56.

Song, M. X., H. Berends, H. Van der Bij, and M. Weggemen. 2007. The effect of IT and co-location on knowledge dissemination. Journal of Product Innovation Management 24 (1): 52-68.

Sunarto, Hari., et al. (2014). Virtual Office Service Management: Proposed Development Model in Indonesia Universities. Indian Journal of Management Science IV (1): 69-77

Teo, T. and Choo, W. (2001). Assessing the Impact of Using the Internet for Competitive Intelligence. Information and Management 39(1):67-83.

Thomke, S. (2006). Capturing the Real Value of Innovation Tools. Sloan Management Review 47(2):24-32.

Wade, M., and J. Hulland. 2004. The resource-based view and information systems research: Review, extension and suggestions for future research. MIS Quarterly 28 (1): 107-42.

Wernerfelt, B. (1984). A resource-based view of the firm. Strategic Management Journal 5 (2) 